\title{
DESAIN GRAFIS SEBAGAI MEDIA UNGKAP PERIKLANAN
}

\section{R. Kuncoro Wulan Dewojati}

\section{Fakultas Bahasa dan Seni Universitas Negeri Yogyakarta}

\section{Abstrak}

Desain grafis lahir dari kebutuhan manusia akan komunikasi melalui bahasa visual sejak abad ke- 19 hingga jaman modern. Mulai dari penggunaan simbol-simbol sederhana sampai perangkat komputer yang canggih. Desain yang berakar dari senirupa murni yang kemudian berkembang menjadi fungsi identifikasi, informasi, instruksi serta Promosi dan Presentasi.

$$
\text { Desain grafis adalah suatu media untuk menyampaikan informasi }
$$
melalui bahasa komunikasi visual dalam wujud dwimatra ataupun trimatra yang melibatkan kaidah-kaidah estetik. Elemen-elemen desain yang utama terliba dalam desain grafis adalah sebagai bahan pokok (ingredients) yang berupa garis, huruf, bentuk (shape) dan tekstur. Sedangkan struktur (structure)-nya adalah pengorganisasian elemen-elemen desain tersebut. Struktur desain yang baik adalah hasil integrasi prinsip-prinsip desain yang akurat pada proses penempatannya. Prinsip-prinsip desain yang utama terdiri dari : keseimbangan (balance), kontras, unity, nilai (value) dan warna.

Sebagai akibat dari proses interaksinya dengan dunia seni, sosial budaya, industri dan perdagangan, maka berbagai corak atau style desain grafis semakin kaya dan berwarna-warni.

Kata kunci : desain grafis, bahasa komunikasi visual

\section{PENDAHULUAN}

Salah satu bentuk bahasa grafis yang juga menggunakan simbol-simbol telah digunakan oleh manusia sejak zaman prasejarah. Hal tersebut terlihat dari beberapa temuan yang memperlihatkan kebiasaan mereka dalam menggunakan bekas-bekas telapak kaki hewan yang tertinggal di permukaan tanah berlumpur sebagai petunjuk atau informasi. Kebiasaan itu dilakukan ketika mereka sedang berburu, sehingga bekas jejak kaki (telapak) hewan tersebut berfungsi sebagai penunjuk arah sekaligus menunjukkan dari jenis apa hewan tersebut. Dengan demikian maka bentuk telapak kaki hewan yang tertinggal di tanah berlumpur tersebut sudah berfungsi sebagai simbol atau "sign" yang di dalam bahasa grafis termasuk dalam kategori fungsi identifikasi.

Kemudian apa yang dimaksud dengan desain grafis ini ? Graphic design is the business of making or choosing marks and arranging them on a surface to convey an idea (Hollis, 1986). Jadi pada dasarnya desain grafis adalah suatu media untuk menyampaikan informasi melalui bahasa komunikasi visual dalam wujud dwimatra ataupun trimatra yang melibatkan kaidah-kaidah estetik. Elemen-elemen desain yang utama terlibat dalam desain grafis adalah sebagai bahan pokok 
(ingredients) seperti halnya dengan terigu, telur, gula dalam pembuatan kue. Hal ini seperti yang dikatakan Peterson (1997) :

"Just like baking a cake, all of the ingredients must be at your disposal to create the finished piece. If you're missing the flour, you may end up with something but it won't be a cake

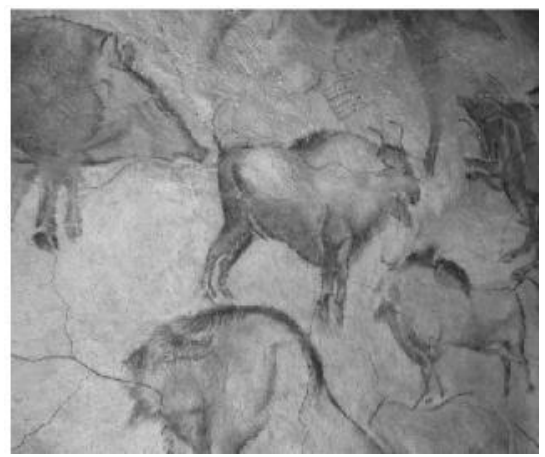

Cave Painting, Antrophos

Google, Wikipedia

Dengan demikian, elemen yang

menjadi bahan pokoknya (ingredients) adalah bentuk-bentuk dasar yang berupa : garis, huruf, bentuk (shape) dan tekstur, sedangkan yang menjadi resep masakannya adalah struktur (structure). Struktur adalah pengorganisasian elemen-elemen desain tersebut. Struktur desain sendiri yang baik adalah hasil integrasi prinsip-prinsip desain yang akurat pada proses penempatannya.

Prinsip-prinsip desain yang utama terdiri dari : keseimbangan (balance), kontras, unity, nilai (value) dan warna.

Unsur-unsur atau elemen dasar seni rupa inilah yang menjadi dasar pijakan dan diorganisir dengan baik demi efektifnya informasi yang akan disampaikan. Selain menggunakan prinsip-prinsip dasar desain, grafis juga melibatkan cita rasa estetis yang berorientasi komersial. Kita telah mengetahui bahwa desain poster film lebih menarik daripada selembar poster berisi imbauan tentang kesehatan di dinding Puskesmas. Hal ini berkat penataan elemen-elemen desain grafis yang melekat padanya serta keterlibatan unsur estetis yang menjadi daya tariknya.

\section{PERKEMBANGAN DESAIN GRAFIS}

\section{Fungsi Dasar Desain Grafis}

Desain grafis sebenarnya sudah menjadi bagian yang akrab dengan kehidupan manusia sejak zaman purba seperti yang diuraikan di atas. Bahkan, sampai zaman modern ini pun desain grafis tetap digunakan sebagai media komunikasi visual yang handal. Meskipun tentu saja grafis yang ditampilkan akan berwujud dan berfungsi sesuai kebutuhan situasi dan kondisi zamannya. Kalau pada zaman purba grafis hanyalah berupa bekas telapak sebagai media informasi atau berupa huruf-huruf paku atau hierogliphe maka pada abad ke 19 sudah berwujud karya poster dan terus berkembang pesat ketika Johannes Gutenberg (1398-1468) menemukan mesin cetaknya.

Pada masa kini, di era teknologi komputer yang paling canggih pun, grafis semakin mengokohkan eksistensinya dalam percaturan komunikasi baik melalui media outdoor, indoor maupun audio visual. Seiring dengan majunya ilmu dan teknologi, desain grafis berkembang menjadi tiga fungsi dasar yakni, (1) identifikasi (identification), (2) instruksi dan informasi, dan (3) promosi dan presentasi.

\section{Identifikasi}

Untuk menyatakan apa dan dari mana sebuah produk diproduksi. Dengan memperhatikan bentuk-bentuk visual tampilan suatu label pada sebuah kemasan, logo sebuah perusahaan, lambang, badge, dan sebagainya kita dapat mengidentifikasikan beberapa aspek yang mendukung keberadaanya. Bentukbentuk desain berupa logo, label kemasan dan sebagainya tersebut masuk ke dalam kategori corporate identity.

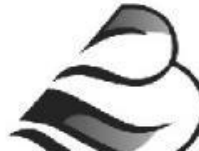 \\ $\mathrm{B} \Lambda \mathrm{T} \Lambda \mathrm{VI} \Lambda \mathrm{\Lambda IR}$}

Corporate identity perusahaan penerbangan Batavia Air

Corporate Identity (identitas perusahaan) adalah salah satu bentuk desain yang berperan pada tiga wilayah cakupannya seperti yang diuraikan Olins (1994). Pertama, produk dan jasa, yakni desain produk, identifikasi pada produk, daftar tarif, petunjuk instruksi pengoperasian dan sebagainya. Kedua, lingkungan, yakni Interior /eksterior: gedung, area penjualan, area resepsionis, kantor, pabrik, show room dan took; tanda (sign): system tanda yang umum sebagai rambu-rambu; eksternal / internal: pameran-pameran; pada pakaian : sebagai atribut di topi, kemeja, jaket dan sebagainya. Ketiga, komunikasi dan informasi, berupa stationery : Letterhead, kartu nama, note book, amplop, visiting card dan sebagainya; Publikasi / pengumuman: pada iklan rekruitmen, promosi produk baru maupun pada programme campaign; kendaraan, terpasang pada armada perusahaan baik, pada armada angkutannya maupun pada kendaraan kantor; dan 
promosi : pada bendera (flag), stiker, balon dan P.O.P materials.

Kemudian struktur bentuk corporate identity dibagi lagi menjadi tiga bagian. Pertama, monolithic, perusahaan yang hanya menggunakan satu nama beserta tampilannya yang khas yang mewakili citra perusahaan tersebut. Contohnya : BMW, Tesco, IBM. Kedua, endorsed: organisasi bisnis yang menggunakan nama dan identitas atas nama grup atau atas nama beberapa perusahaan di dalamnya. Contohnya : General Motor, United. Ketiga, branded: perusahaan yang memproduksi barang lebih dari satu jenis dengan nama merek yang bermacam pula dimana merek-merek tersebut tidak ada hubungannya dengan nama perusahaan. Contohnya : Procter \& Gamble, Unilever.

Corporate identity adalah identitas yang kebanyakan berorientasi pada bisnis padahal selain dari itu masih banyak lagi hal-hal lain yang dapat diidentifikasi sebagai simbol identitas yang mempunyai nilai informasi / bobot ungkap. hal tersebut dapat sebagai contoh, seperti yang terdapat pada relief-relief candi, prasasti-prasasti dan ukiran yang mengandung simbol-simbol yang terdapat pada pintu gerbang keraton yang mana ukiran-ukiran tersebut mempunyai nilai informasi sekaligus identifikasi. Meskipun hal tersebut di atas belum jelas dan masih bias, sehingga dapat dikategorikan sebagai simbol grafis, namun demikian maksud yang dikandungnya memiliki kesamaan fungsi.

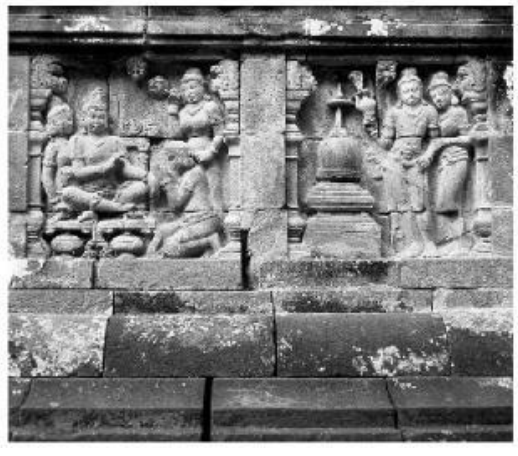

Relief Candi Borobudur

mempunyai nilai informasi dan identifikasi

Instruksi dan informasi

Media informasi yang menggunakan simbol-simbol grafis dalam menggambarkan posisi suatu tempat, arah atau pun petunjuk/ instruksi tentang suatu cara yang disertai dengan skala perbandingan. Contohnya antara lain : peta lokasi, gambar instruksi, diagram / chart, gambar kronologis suatu peristiwa dan sebagainya.

Pada tahun 1930 Otto Neurath mempelopori penciptaan sebuah peta yang berisi informasi tujuan kereta bawah tanah (subway) di kota London. Neurath adalah orang pertama yang menciptakan sebuah peta yang menggunakan simbolsimbol grafis dan tipografi yang disebutnya dengan istilah Isotype (International
System of Typographic Pictrorial Education) atau dapat juga disebut dengan istilah Viennese method.

System Isotype yang diperkenalkan Neurath ini terdiri dari dua aturan main. Pertama, simbol grafis yang menggambarkan kuantitas harus digambarkan sesuai dengan jumlah kuantitas yang diwakilinya bukan dengan satu symbol yang digambarkan dengan bentuk yang besar. Kedua, perspektif tidak diperlukan di dalam visualisasinya.

Studio Isotype bertanggung jawab dalam menghimpun data dan merancang atau memodifikasi simbol-simbol grafis dalam satu lay-out yang informatif. Kegiatan selanjutnya adalah menyiapkan materi yang akan dieksekusi dalam bentuk cetak dan sebagainya.

Pada tahun 1993 seorang insinyur bernama Harry Beck menyempurnakan visualisasi peta milik Otto Neurath. Beck mengubah tampilan peta versi Neurath dengan bantuan grid-grid berbentuk octagonal. Tampilan informasi rute jalur kereta dengan stasiun-stasiunnya menjadi lebih informatif.

Perancang grafis Harry Beck ( 1903-1974) menciptakan peta bawah tanah London (London Underground Map) pada tahun 1931. Sebuah pekerjaan abstrak yang mengandung sedikit hubungan ke skala fisik. Beck memusatkan pada kebutuhan pengguna dari bagaimana cara sampai dari satu stasiun ke stasiun yang lain dan dimana harus berganti kereta.

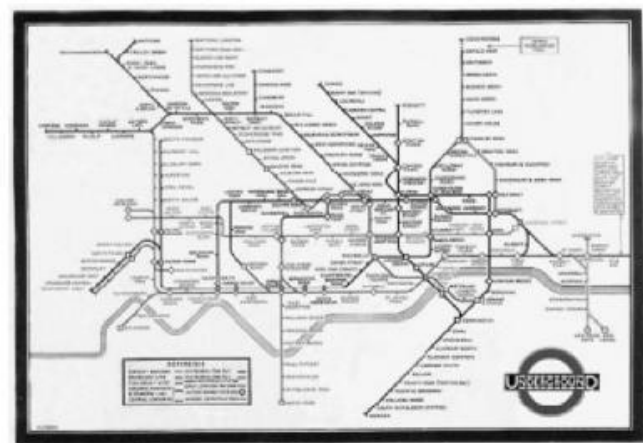

Contoh lain yang masih berkenaan dengan system Isotype ini adalah poster karya Theyre Lee-Eliot yang berisi iklan tentang jasa pengerah tenaga kerja. Dalam karyanya Elliot menggunakan elemen grafis sebagai simbol dari angka-angka statistik. Dengan cara ini informasi yang disampaikan menjadi lebih menarik dan lebih meyakinkan.

Promosi dan Presentasi

Bagian dari fungsi desain grafis yang berhubungan dengan bidang pemasaran adalah promosi sedangkan media yang digunakannya dapat juga 
disebut dengan media presentasi yang dewasa ini sudah didukung oleh perangkat teknologi komputer.

Media promosi dan presentasi pada desain grafis yang berbentuk iklan atau advertensi meliputi pada dua media. Pertama, media Lini-atas (Above the line media) terdiri dari iklan-iklan yang dimuat dalam media cetak, media elektronik (radio, televisi dan bioskop) serta media luar ruang (billboard dan bus panel). Kedua, media Lini bawah (Below the line media) terdiri dari seluruh media selain media di atas seperti direct mail, brosur, pameran, point of sale display material, kalender, agenda ataupun souvenir (Kasali, 1995)

Secara umum dapat dikatakan bahwa fungsi desain grafis pada dua bidang media di atas bertugas menyampaikan pesan secara informatif, persuasif dan atraktif. Dengan segala pertimbangan yang mendukung keberhasilan suatu media iklan maka dewasa ini desain grafis tidak berdiri sendiri tapi sudah pula melibatkan cabang ilmu lainnya, misalnya dengan ilmu komunikasi sosial, psikologi, pemasaran, atau ekonomi dan tentu saja teknologi.

\section{Perkembangan Desain Grafis Abad ke-19}

Cikal bakal desain grafis pada awalnya berasal dari kegiatan seni rupa murni (fine art) khususnya pada seni cetak (grafis) yang pada saat itu sudah menggunakan teknik cetak batu (lithography). Suatu teknik cetak yang diciptakan oleh seorang Austria bernama Alois Senefelder tahun 1796.

Kemudian dengan memanfaatkan teknik inilah seorang seniman Perancis bernama Jules Cheret pada tahun 1866 mulai memproduksi poster-poste komersialnya. Dengan teknik cetak litho ini memungkinkan untuk mencetak poster dalam jumlah 10.000 eksemplar perjam dan dapat membuat poster dengan ukuran besar. Karena faktor ini jugalah maka poster menjadi salah satu medi yang paling handal dalam mendukung pemasaran dan promosi pada masa-masa tersebut. Meskipun saat itu sudah ditemukan suatu sistem cetak letter-press untuk mencetak huruf namun poster yang ditampilkan tidak menggunakan huruf yang dicetak. Sang desainer akan menuliskan langsung pada master cetakan dengan tulisan yang dibuat dengan tangan.

Keberhasilan Cheret dalam memproduksi poster-poster komersialnya diikuti dan dikembangkan oleh seniman-seniman lainnya seperti Pelukis postImpressionist dan ilustrator art nouveau Prancis, Henri de Toulouse-Lautrec melukiskan banyak sisi Paris pada abad ke sembilan belas dalam poster dan lukisan yang menyatakan sebuah simpati terhadap ras manusia. Walaupun lithography ditemukan di Austria oleh Alois Senefelder pada tahun 1796, Toulouse-Lautrec membantu tercapainya peleburan industri dan seni. Seniman ini mengembangkan teknik cetak lithografi ini sebagai media ekspresi seni rupanya selain sebagai media ungkap komunikasi visual bersifat komersial, sehingga tampilan poster-poster seniman ini lebih banyak muatan seni murninya.

Poster sebagai media komunikasi visual yang handal pada zaman itu karena selain memang teknologi belum berkembang pesat juga penggunaan desain grafis sebagai media promosi dan iklan adalah sesuatu yang masih baru.

Oleh sebab itu maka sejak itu pula desain grafis menjadi bagian dari dunia industri. Khususnya pada bidang pemasaran. Hal ini benar-benar memberi pengaruh positif, baik didalam meningkatakan margin penjualan maupun dalam pengaruhnya terhadap citra produk yang ditampilkan.

Perkembangan Desain Grafis Abad ke-20

Era cetak batu litho yang menghasilkan poster-poster komersial berakhir dan dimulailah suatu perluasan fungsi desain grafis yang berimplikasi pada bidang-bidang lain yang masih berhubungan dengan bidang komunikasi visual. Usaha ini dimulai dengan pencetakan buku-buku sastra yang dirancang dengan berbagai format dan desain yang bercorak dekoratif dan menghias. Tokoh yang produktif atau menghasilkan tidak kurang dari lima puluh judul buku antara tahun 1891 sampai 1896 adalah William Morris dengan Morris's Kelmscott Press perusahaan percetakan yang ia punyai.

\section{Massa Art Nouveau}

Menjelang akhir abad ke sembilan belas lahir suatu gerakan seni rupa di daratan Eropa dan Amerika yang disebut dengan istilah Art Nouveau. Istilah ini di Jerman dikenal dengan Jugendstil, di Perancis dengan Le Style Moderne, di Austria dengan Secession, di Itali dengan Stile Liberty dan di Spanyol dengan Modernista. Gaya desain yang ditampilan Art Nouveau ini bercorak dekoratif didominasi dengan garis-garis ornamental yang berasal dari unsur-unsur esensi flora.

Gaya Art Nouveau yang lahir di Inggris ini banyak mendapat pengaruh dari unsur-unsur seni kerajinan (craft) dan mempengaruhi pula di bidang seni rupa murni (fine art) yang menjadi sebuah fenomena pada zamannya. Sebagai suatu tren yang tengah mewabah pada era tersebut, citra Art Nouveau merefleksikan gagasan-gagasan baru, semangat berkesenian yang baru serta memperngaruhi segi-segi sosial masyarakat Inggris pada waktu itu. Tercatat beberapa desainer grafis yang patut disebut sebagai pelopor di antaranya seperti Charles Rennie Mackintosh dari Glasgow dengan karya-karyanya yang sempat menjadi acuan para desainer di kota Wina (Austria), Margaretj, Famces Macdonald, George Walton, Aubrey Beardsley dan Walter Crane.

Kemudian pada tahun 1896 di Jerman lahir pula suatu gerakan seni rupa semacam Art Nouveau yang mulai mempublikasikan karya-karyanya melalui majalah De Jugend. dan dengan nama majalah inilah akhirnya menjadi popular 
dengan istilah jugendstil. Melalui majalah ini pula para desainer yang kebanyakan juga sebagai seniman aktif menghasilkan karya-karya senirupa terutama desain grafis yang berfungsi sebagai media yang menjebatani antara keberadaan seni dan masyarakat.

\section{SIMPULAN}

Desain grafis lahir dari kebutuhan manusia akan komunikasi melalui bahasa visual sejak abad ke- 19 hingga jaman modern. Mulai dari penggunaan simbol-simbol sederhana sampai perangkat komputer yang canggih. Desain yang

berakar dari senirupa murni yang kemudian berkembang menjadi fungsi Identifikasi, Informasi, Instruksi serta Promosi dan Presentasi. Sebagai akibat dari proses interaksinya dengan dunia seni, sosial budaya, industri dan perdagangan, maka berbagai corak atau style desain grafis semakin kaya dan berwarna-warni.

Kesimpulannya desain grafis yang merupakan bagian dari Desain

Komunikasi Visual mulai berkembang dalam situasi yang saling mempengaruhi atau hubungan interelasi baik dalam gaya dalam desain grafis itu sendiri maupun dalam hubungannya dengan masyarakat. Sedangkan perkembangan desain grafis di Indonesia nampaknya masih akan terus tumbuh dan berkembang serta mempunyai prospek yang cerah dengan adanya Indonesia sudah masuk kedalam jaringan ekonomi global.

\section{DAFTAR PUSTAKA}

Amborse, Gavin \& Harris, Paul, The Visual Dictionary of Graphic Design, London 2006

Barnicoat, Jhon, Poster A Concise History, London, Themes and Hudson, 1991

Hollis, Richard, Graphic Design A Concise History, London, Themes and

Hudson, 1994.

Olins, Wally, Making Businnes Stategy Through Design, London, Themes and Hudson, 1994

Kasali, Rhenald. 1995Manajemen Periklanan. Jakarta: PAU-Ekonomi- UI.

Sihombing, Danton. 2001. Tipografi dalam Desain Grafis, Jakarta: Graffiti Press 